\title{
REPORT OF A CASE OF TUMOR OF THE HYPOPHYSIS WITHOUT ACROMEGALY.*
}

By Cinarles W. Burr, M.D., and Dayid Riesman, M.D.

The point of intercst in the case we report, or rather the point we wish to bring up for discussion, is the presence of hypophysial disease without any symptoms of acromegaly. We believe, for reasons which will appear later, that acromegaly is due to the disease of the hypophysis, and we purpose to use this case, which seemingly combats stich an opinion, in an endeavor to explain the alssence of acromegalic symptoms in some cases of discase of the hypophysis.

The paticnt, a white woman, 43 years old, was admitted to the Philadelphia Hospital on July 26th, $\mathbf{1} 897$, on account of complete blindness. Her personal history was vague, and her heredity unknown. The only information that could be obtained from her was that she had been blind five years, and that her ovaries had been removed, by whom and for what reason she could not tell. Dr. Charles A. Oliver found the following ocular condition: O. D., iris dilated fully and irresponsive to light; pupil round; slight horizontal nystagmus; marked post-neuritic atrophy. O. S., iris fully dilated and irresponsive to light; disk still nore atrophic from past inflammation than was the right.

She was transferred to the nervous wards with a diagnosis of brain tunor. Physical examination revealed little. She was a thin, anemic, blue-lipped woman. Her gait was neither paralytic nor ataxic, but was a little stiff. Rigidity, not very marked, was observed in both legs, especially in the right. The station was good. Both knee-jerks were increased, quick and spastic. On the right side ankle clonus was persistent and true; on the left it was abortive; that is, it ceased after three or four irregular contractions. The plantar jerk was present on both sides. Sensibility to touch and pain was normal on the $1 \mathrm{cgs}$, arms, and face. Her answers were so contradictory that it was impossible to determine the condition of the sense of smell. The heart and lungs were normal. Examination of the blood gave rell corpuscles, 4,380,000; white corpuscles, 7,800; hemo-

* Read before the Philadelphia Neurological Society, October 24, I 898 . For discussion on this paper see page 43 . 
globin, 55 per cent. The eosinophiles were much increased. The urine did not contain albumin, sugar, or casts. The mental state of the patient was much more striking than the physical. At first she was simply dull and listless, disinclined to talk, sitting hour after hour with head bowed on the chest, moving only to go to her meals and to bed, answering in monosyllables all questions put to her-in short, seeming to be most content when undisturbed. This condition continued for several months, and then changed. While still remaining ordinarily quiet and self-contained, she became at times most obscenely witty and cynically jocose. Trifling as it may seem to regard jocosity and obscenity as symptoms, they were in truth striking. Whether they were due to mere viciousness or to disease it is not possible to decide, but it is not impossible that they were due to disease, like symptoms having been noted in similar cases. During the last months of her life she became dull and stupid again, and suffered several attacks of coma, coming on suddenly and lasting several hours. She died in coma on the Igth of April, I 898.

The necropsy was made two days after death. The body was well developed and fairly muscular. Rigor mortis was very slight. Post-mortem lividity was marked. An old scar was present in the linea alba. The veins upon the chest were dilated. There was no enlargement of the extremities (hands or feet), or of the face, nor any deformity of the spinal column. There was an enormous deposit of preperitoneal fat five centimeters thick, and the omentum, mesentery, and mesocolon were also very thick with fat. The bladder was distended and projected five centimeters above the symplyysis pubis. The liver was small and contracted, and failed to reach the costal margin by five centimeters. There were numerous adhesions in both iliac fossæe, ancl in the pelvis. The appendix was long, thin, and bound down at its tip to the pelvic wall. The right ovary could not be founcl. A part of the right Fallopian tube was present and acherent to a coil of small intestines that was prolapsed into the pelvis. On the left side also the ovary could not be found, and no part of the Fallopian tube remained. The round ligament was present. The uterus was adherent to the rectum on the left side. The diaphragm extended to the fourth interspace upon the left side, and to a corresponding point upon the right. There was quite a little bloody fluid in both pleural cavities. The lungs overlapped in front. A little of the thymus gland remained. There was a slight excess of clcar fluid in the pericardial sac. The heart weighed 2 Io grams. The right auricle was slightly distended with liquid blood. The heart was small in proportion to the size of the body. The pulmonary valve was normal. The aorta was distinctly thickened. The 
interior showed "willow-tree" markings, beginning sclerosis, and some yellowish patches above the sinuses of Valsalva. The mitral valve was thickened, and showed a few yellowish patches. The heart muscle was dull brown, marked by whitish strix. The cavity of the left ventricle was small, and its wall twenty centimeters thick. Both lings were edematous, but otherwise normal. The spleen was small, but showed no evidence of disease. The kidneys were somewhat small, and the capsules stripped with difficulty. On section the substance

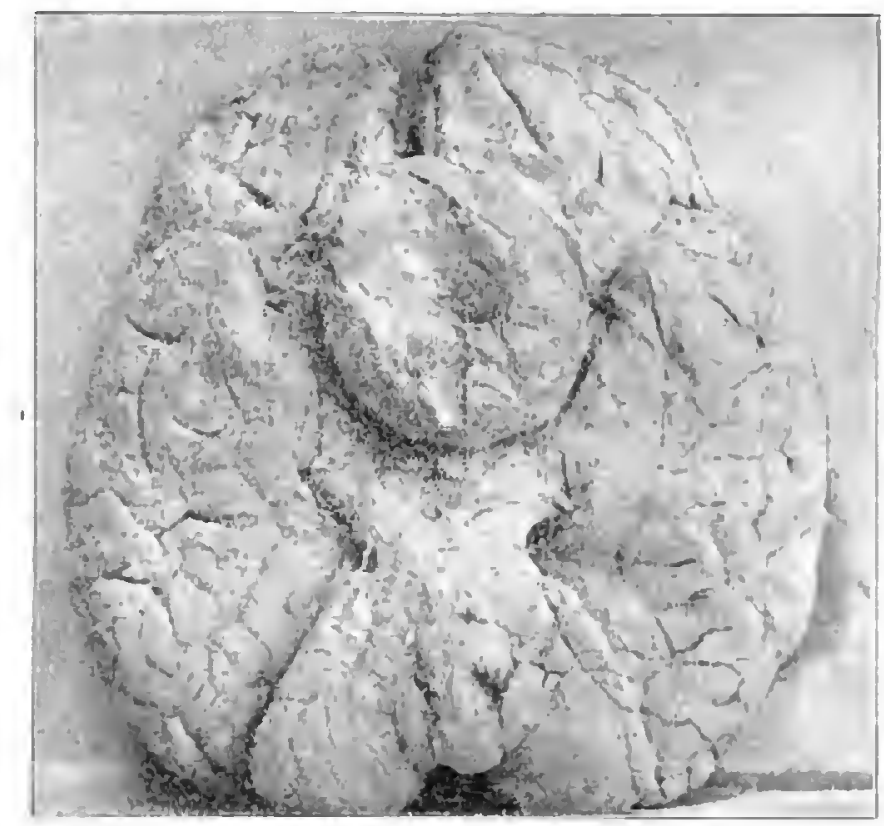

F1G. I. Tumor of the hypophysis.

was congested, dark, both pyramids and cortex being a purplish red. The cortex was not diminished in thickness, its consistency was slightly increased, and the cut vessels gaped. The liver was small and hard. The calvarium was hard, ivory-like, and the diplœ absent. In the middle line in front the calvarium was one-half centimeter thick. On the inner surface it was smooth, the grooves of the blood vessels were fairly well marked, and there were a few Pacchionian depressions. In front of the sella the bone was a little abraided, and the cavity itself was somewhat enlarged. The brain bulged. considerably 
when the dura was removed. The whole interpeduncular space anterior to the mamnillary bodies was oceupied by a mass about as large as a lemon, on the under surface of which the hypophysis appeared. (See lig. 1.) The tumor filled the space between the tips of the temporo-sphenoidal lobes, and was adherent to the membranes over the base. Its anteroposterior diameter was six centimeters, its lateral five and a half, and its depth three centimeters. The hypophysis (which in the plate is marked by a piece cut out; see lig. 1.) was one and a half centimeters transversely and one centineter anteroposteriorly. The optic chiasm could not be discovered. both third nerves were very much flattened. Anteriorly, the tumor extended a centimeter in front of the corpus callosum. ()n looking down upon the brain, the corpus callosum was seen to be much arehed, with the convexity upward. The corpora striata on both sicles, especially the left, bulged into the lateral ventricles. The tumor on section was grayisl, not very hard, granular, and apparently not hemorrluagic.

The pathologic diagnosis was tumor of the base of the brain, probably originating in the infundibulum; absence of both ovaries, pelvic adhesions, beginning cirrhosis of the liver, slight interstitial nephritis, ostcosclerosis of the skull, hyperplastic sclerosis of the cribriform of the ethmoid bone, and edema of the linins.

Microscopic Examination.-Pieces of the tumor were fixed and hardened in alcohol, imbedded in celloidin, cut into thin sections, and the latter were stained with hematoxylin, hematoxylin and eosin, carmine, and Van Gieson's stain. The tumor is a spindle-celled sarcoma, with a well narked tendency on the part of the cells to an alveolar arrangement. (On the surface the tumor is covered by a thin capsule of fibrocellular tissue, which sends short trabecula into the growth. This capsule contains a few blood vessels and a number of mast cells, mostly of small sizc, scattered irregularly through it. The cells of the tumor are large spindle cells with large nuclei, and run in concentric groups, forming large bundles, or whorls, of considerable size. In the center of these the cells are very near together, on account of pressure, and the nuclei appear as if piled upon one another, so that a semblance of giant cells is produced, but no true giant cells are present. The alveolar. arrangement referred to is not produced, except just near the surface, by a true stroma, but merely by a vertical grouping of the spindle cells.

Another section which had been carried through what was consideref at the necrops the remains of the hypophysis. shows the structure of the latter organ distinctly, and is that 
from which the accompanying drawing has been made. (See Fig. II.) We find here small epithelial cells with darkly staining nuclei, closely aggregated, and here and there assuming a tubular arrangement. The tissue evidently represents the remains of the anterior lobe of the.hypophysis. The connective tissue is slight in amount, but blood capillaries are abundant and well filled; colloid material is nowhere seen. Directly continuous with the glandular portion of the hypophysis is a small

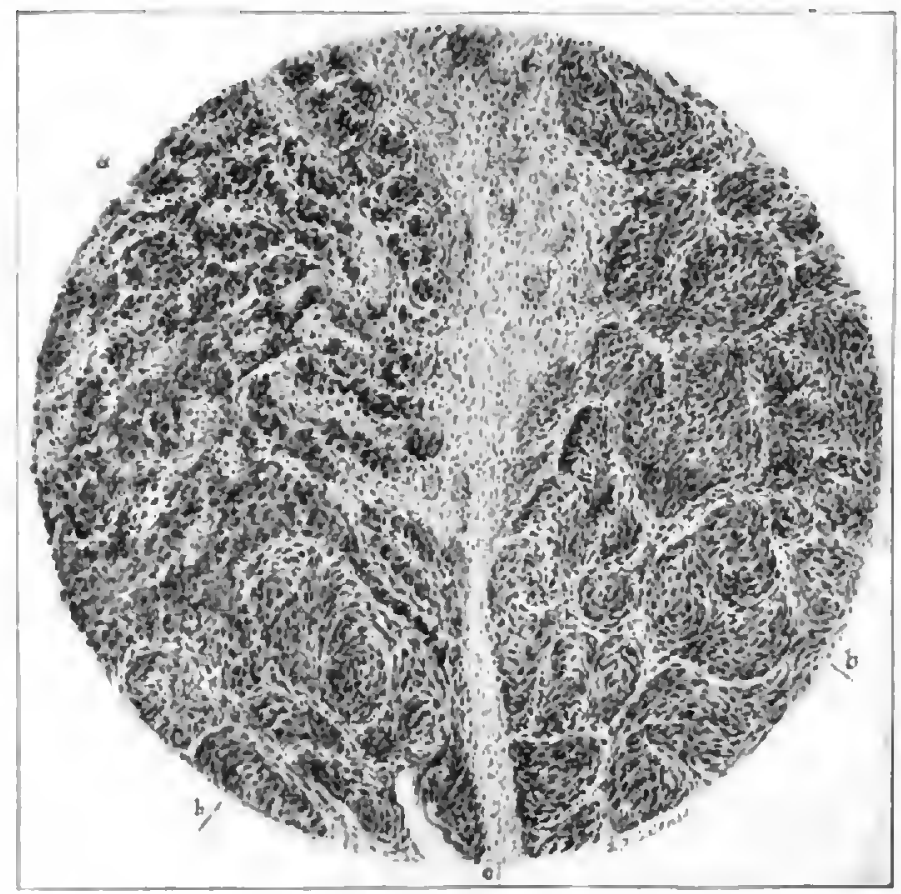

FIG. II. a-Remains of anterior lobe of hypophysis, with dila: ed blood vessels. b b-Spindle-cell sarcoma. c-Band of fibrous tissue. (Tissue fixed in alcohol, embedded in celloidin, and section stained with hematoxylin. Zeiss oc. 3, ob. A A.)

mass of lymphoid tissue, possibly a portion of the posterior lobe of the organ.

In one part of the section the hypophysis is sharply separated from the tumor by a broad band of fibrous tissue, as shown in the figure; elsewhere no sharp line of demarcation is observable, and in several places long, winding processes of hypophysial tissue are traceable into the new growth. The 
cells in these long processes show a well marked tubular disposition, are polylnedral, and are accompanied by connective tissue and blood vessels. The processes can be traced for a long distance and are finally lost in the tumor. The tumor is practically free from degeneration.

The nervous tissue included in the section is greatly degenerated; it is loose, alveolar, and resembles in its reticular character mucoid connective tissue. The condition is well described as cribriform. The ganglion cells have lost their processes and stain indistinctly. There is no hyperplasia of the neuroglia, but in places the number of capillaries is distinctly increased.

To sum up: Wie have a woman whose sole subjective symptom is blindness, which came on several years before deatl, and who, under examination, is found to have post-neuritic atrophy in botln eyes; who is usually dull and stupid, but at times very bright; who has persistent ankle clonus on one side, some rigidity in the legs and spastic knce-jerks; who has several times beconte comatose, and finally dies in coma.

The diagnosis of brain tumor with such a combination of symptoms is not difficult and is entirely justified. To locate the tumor is nore difficult, and we found it impossible. Thus far in localization we could go; the tumor must be so situated as to encroach upon but not to destroy, nor seriously interfere with, both motor tracts, the right the more especially. Had the case been seen, earlier the type of hemianopsia characteristic of hypophysial disease might have been present, but when the patient came under observation it was too late. $\mathrm{Had}$ it been safe to depend on her statements as to the power of smell, much light might have been thrown upon the matter, but she was entirely unreliable. Post morten there is found a tumor involving, but not destroying, the hypophysis.

The opinion that acromegaly is due to disease of the hypophysis has rapidly gained adherents, until now it is accepted by the majority of writers. This opinion has not been formed without careful thought and wide and exhaustive discussion of both sides of the question. It is based upon the following evidence: First, that from post-mortem examination:

In Hinsclale's ${ }^{1}$ carefully prepared list, numbering fiftyseven cases, and including all admitted by every one to be in-

1 Boylston Prize Essay. Medieine. Iune to Septenher. I898. 
stances of acromegaly, the hypopliysis was diseased in all. In the cases reported by Sarbo, liriedrcich and Arnold, and Bonardi, the hypophysis is saicl to have becn normal, but there is some doubt about the correctncss of the diagnosis. In William Hunter's" casc, reported recently, there was vascular hypertrophy of the hypophysis with hemorrhages.

This fact, that in sixty-one cases, including even those in which there is some doubt about the diagnosis, fifty-cight showed disease of the hypopliysis, proves that there must be some close relation between the two conditions. It cannot be mere accielent. Were it true, as has been clained, that discasc of the lypoplysis is merely a symptom of acromegaly, the lesion of the gland wonld always be the same, whereas it has been founcl to vary very much: in sone cases being a so-ealled simple hypertropliy; in others a malignant growth.

Seconcl, the evidcnee fron the clinieal history.

In a very large number of eases there are symptoms of tumor of the brain (headache, vertigo, optic neuritis), and in the cases which come carly under medical observation, hemianopia of the type indicative of hypophysal discase is not infrequent. Inthermore, the risual symptoms increase with the increase of the bony symptoms, never beginning rery late in the diseasc and often anterlating by a consiclerable time the hypertrophy. The importance of this is that the visual symptoms serve in a rough way to measure the inerease in the size of the hypophysis, and conscquently the amount of discase.

Thircl, the argument from analogy with discase of the thyroid gland.

The discovery of the functions of the duetless glands is of very recent datc. Not so many years ago, had any one said that the thyroid gland stood in any relation to the nutrition of the body, he would not have found any hearers. To-clay every onc admits that nyxcdema is caused by thyroidal diseasc. There is then in the known nature of things no reason why hypophysial discasc may not cause acromegaly.

Against the view of the hypophysial origin of acromegaly there is the following cvidence: First, there may be disease of the hypophysis without any signs of acromegaly. This is mdeniably truc. Many such cases have becn reported. Weir

\footnotetext{
${ }^{2}$ Brit. Med. Jour.. March 19, 1898.
} 
Mitchell's classical case of aneurism of an anomalous artery of the circle of Willis, often quoted in this connection, lias in reality little bearing, for it was reported quite a long time ago, there is no description of the condition of the extremities, and when the brain was received by him it was not in condition for any minute study. The hypophysis is not described. In none of the reported cascs known to us has it been shown that the glandilar part of the organ was eompletely destroyed; in not a few no microscopic examination was made, and in others only sufficient to determine the nature of the growth. This is the value of the ease that we report. It shows that though, to the naked eye, the gland may appear greatly discased or indeed destroyed, still it may contain much licathy glandular tissue.

Though we are ignorant whether the hypophysis contains ordinarily more glandular tissue than is needed for the proper performance of its functions, yet by analogy it is lighlily probable that it does. In all other glinds, secretory or exeretory, there is a surplus of tisste. or at least if a part be lost by accident or discase the remainder may do the same amount of work as was clone by the entire orgatis. Nature is a spenclthrift, and it is hardly fair to accuse her of niggardliness in the matter of one organ. The importance of a remnant of an organ is well shown in the thyroid. Operative myxelema does not follow the partial removal of the thyroicl gland, even if the part left is very small, but cloes follow when the entire organ is renoved. The same thing n11ay be true of the hypoplyysis: namely, that a small amount of glandular tissue may do the work of the whole, or at least nuay be sufficient to inhibit excessive growth in the bony extremities. There may be, and probably are, other functions as yet undiscovered, requiring a greater amount of gland for their performance.

Second, the existence of acromegaly without visual symptoms. Dercum has reported two such cases, and there have been not a few others. If these cases come to necropsy and the hypophysis is found normal, their value will be greatly increased.

Third, there is not a single ductless gland in the borly that has not been found diseased, and it would be as proper to say that disease of any one of them caused acromegaly as of any 
other. It is true that all or almost all have becn found diseased, but not any one except the hypophysis in any large number of cases. We cannot say of any othcr one that it was pathologic in fifty-eight out of sixty-one necropsies. Furthermore, each of them is frequently discased without any sign of acromegaly.

Fourth, the cvidence from experimental destruction of the gland. The hypophysis has been destroyed without causing acromegaly (Marinesco, Varsalc, Succhi.) The acceptance of this evidence assumes the identity of function of the gland in man and dogs. This identity is assumcd, not proven. We know little of the function of the gland in man, and less concerning it in other animals. The same evidence would prove that myxedema has no relation with the thyroid gland, for its removal in dogs causes entirely different, non-myxedemoid symptoms. Furthermore, acromegaly may be due to a perversion of function and not to its abolition.

Fifth, the failure of the therapeutic test. No patient has been eured by the use of hypophysial extract. This has manifestly little weight, and no one has laid grcat stress upon it.

Balancing all the eviclence on both sicles of the question, we feel justified in believing that acromegaly is caused by disease of the hypophysis, and that for its production the lesion must be complete, i. e., must affect the entirc glandular structure. 